Aksiologiya: Jurnal Pengabdian Kepada Masyarakat

Vol.5, No. 2, Mei 2021 Hal 233 - 240

ISSN 2528-4967 (print) dan ISSN 2548-219X (online)

\title{
Implementasi Pemasaran Dan Pencatatan Penjualan Sederhana Pada UMKM Tanaman Hias Kecamatan Arcamanik Kota Bandung
}

\author{
Dodi Supriyanto ${ }^{1}$, Vania Rakhmadhani ${ }^{2}$, Cecep Taufiqurrohman ${ }^{3}$ \\ 1,2,3 STIE Ekuitas Bandung \\ Email: dodisupriyanto22@gmail.com¹,vania_rakhmadhani@yahoo.com², \\ ctaofiq@yahoo.com ${ }^{3}$ \\ ${ }^{*}$ Corresponding author: penulis ${ }^{1}$
}

\begin{abstract}
ABSTRAK
Pengabdian kepada masyarakat ini dilakukan di usaha tanaman hias yang merupakan produk dari jenis usaha mikro kecil dan menengah (UMKM) yang terdiri dari 12 (Dua belas) pedagang tanaman hias dengan kepemilikan yang berbeda-beda, dan dengan jarak yang saling berdekatan. Kegiatan ini bertujuan untuk mewujudkan kegiatan pemasaran yang optimal dan berdaya saing serta pencatatan keuangan yang sederhana dalam membantu menjalankan usahanya. Permasalahan yang dialami oleh pengusaha tanaman hias, diantaranya pemasaran yang belum optimal, bukti transaksi yang belum memadai, terbatasnya modal serta sulitnya akses kepada lembaga keuangan. Metode yang digunakan dalam menyelesaikan permasalahan permasalahan tersebut diawali dengan survei ke lokasi, tahap pelaksanaan memberikan pendampingan dalam pemasaran ke konsumen melalui pelatihan pemasaran yang efektif dan pendampingan dalam pencatatan transaksi yang ada di tempat tanaman hias, tahap terakhir yaitu tahap monitoring dan evaluasi. Kegiatan ini diharapkan dapat membantu pengusaha tanaman hias dalam melaksanakan kegiatan pemasaran kepada konsumen dan pencatatan keuangan yang benar dan sesuai standar akuntansi.
\end{abstract}

Kata kunci: Implementasi Pemasaran; Pencatatan Penjualan Sederhana; UMKM

\section{Implementasi Marketing And Simple Sales Recording on UMKM Ornamental Plants Arcamanik Sub-District Bandung}

\begin{abstract}
This community service is carried out in the ornamental plant business which is a product of small and medium micro enterprises (UMKM) consisting of 12 (Twelve) ornamental plant traders with different ownership, and with close proximity to each other. This activity aims to realize optimal and competitive marketing activities as well as simple financial recording in helping to run its business. Problems experienced by ornamental plant entrepreneurs, such as optimal marketing, inadequate transaction evidence, limited capital and difficult access to financial institutions. The method used in solving the problem begins with a surveyto the location, the implementation stage provides a psideline in marketing to consumers through effective marketing training and assistance in recording transactions that are in place of ornamental plants, the last stage of which is the monitoring and evaluation stage. This activity is expected to assist ornamental plant entrepreneurs in carrying out marketing activities to consumers and correct financial recording and in accordance with accounting standards.
\end{abstract}

Keywords: Marketing Implementation; Simple Sales Recording; UMKM 


\section{PENDAHULUAN}

Pedagang Tanaman hias berdiri padatahun 1988 yangberalamatdiJalan Pacuan Kuda Kecamatan Arcamanik, Kelurahan Sukamiskin Kota Bandung 40293. Awal berdirinya terdapat 22 (dua puluh dua) tempat tanaman hias, lahan yang digunakan usaha tanaman hias dikelola oleh Pemerintah Provinsi Jawa Barat. Retribusi saat masih dikelola oleh Pordasi (Persatuan Olahraga Berkuda Indonesia) iurannya sebesar Rp 150.000 per bulan. Karena keterbatasan lahan usaha yang akan di bangun sarana olahraga SPORT Jabar Arcamanik yang awalnya 22 tempat tanaman hias dipangkas menjadi 12 tempat tanaman hias sampai sekarang. Tanaman hias setelah dibangung SPORT Jabar dikelola retribusinya oleh RW (Rukun Warga) 06 sebesar Rp 60.000,-per bulan yang digunakan untuk keamanan lingkungan, biaya kebersihan dan kas RW.

Dalam menjalankan aktivitas perdagangan, Pedagang tanaman hias menyewa lahan bangunan sebagai tempat aktivitas perdagangan. Selain itu, Pedagang tanaman hias ini juga ditunjang oleh adanya berbagai jenis tanamanbungayang variatifdigunakan untuk memberikan pilihan bagi para pelanggannya. Disamping tempat tanaman hias yang terawat dengan baik, juga menyediakan berbagai tempat untuk penanaman bunga yang diminati oleh para pembelinya.

Bibit/ Benih, Media Tanam, Pupuk, Pestisida, Mulsa Plastik (Plastik penutup media tanam), Sungkup (Plastik peutup bunga atau daun), Lahan Parkir dan Akses ke jalan raya sangat mudah itu merupakan Sarana dan prasarana yang dimiliki oleh Pedagang tanaman hias dalam menunjang kegiatan usahanya

Berdasarkan kondisi usaha, Pedagang tanaman hias memiliki omset per bulan sekitar Rp 10 juta. Omset tersebut diperoleh dari penjualan tanaman hias yang dilakukan dengan tradisonal. Artinya, penjualan tanaman hias dilakukan dengan menunggu pembeli yang datang. Usaha perdagangan tanaman hias ini termasuk usaha mikro yang omsetnya kurang dari Rp 300 juta per tahun. Usaha mikro ini merupakan salah satu penyokong ekonomi nasional. Namun, UMKM sering dihadapkan pada permasalahan yang klasik seperti terbatasnya permodalan, pemasaran yang tidak terkonsep, pengelolaan keuangan yang bercampur dengan keuangan rumah tangga dan manajemen yang tidak jelas. Hal ini senada dengan pendapat (Jayanti Mandasari, Dewi et all, 2019) menyatakan bahwa jaringan pemasaran masih lemah dan sering kalah bersaing. Usaha ini bilamana dikelola dengan baik dan pola pemasaran yang efektif, tidak hanya sebagai sumber penghidupannya saja, melainkan juga bisa sebagai usaha yang menguntungkan pada akhirnya bisa membuka lapangan pekerjaan dalammembantu program pemerintah, khususnya pemerintah daerah.

Usaha tanaman hias ini dapat dikembangkan menjadi objek wisata bunga yang lebih terintegrasi dengan pihak yang berkepentingan. Seperti Dinas Pertamanan, Dinas Pariwisata 
dan Dinas Perdagangan termasuk Pemerintah Daerah Kota Bandung selaku pemangku kepentingan. Wisata bunga ini akan menjadi daya tarik bagi masyarakat apabila ada penataan tempat berjualan, pengelompokan jenis bunga dan adanya sarana pendukung yang memadai, antara lain area parkir, mushala, toilet dan juga pendukung lainnya. Bilamana hal seperti ini dapat terwujud, maka belum secara optimal apalagi menggambarkan laporan keuangan sesuai standar akuntansi.

Kegiatan usaha dalam bentuk dan jenis apapun itu harus didukung dengan pemasaran yang baik (Kotler, 2016 : 11). Secara tegas Kotler, menjelaskan kegiatan pemasaran sederhana dalam gambar sebagai berikut:

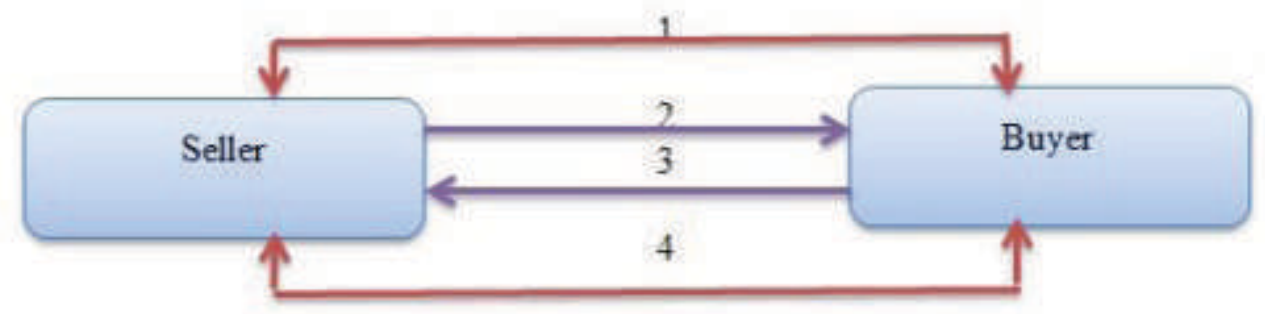

Keterangan : 1. Communication, 2. Goods/Services, 3. Money, 4. Information

Gambar 1 Kegiatan Pemasaran

sumber pendapatan bagi pedagang tanaman hias ini dapat dihasilkan dari berbagai sumber.

Usaha dari tanaman hias ini diperlukan strategi sehingga dapat menghasilkan keuntungan yang berdaya guna dan berkesinambungan. startegi pemasaran adalah cara untuk mendapatkan persaingan dengan mengedepankan keunggulan produk barang/jasa yang berkesinambungan (Jayanti Mandasari, Dewi et all, 2019).

Pada saat dilaksanakan penelitian dan pengabdian, semua pedagang tanaman hias ini hanya mempunyai catatan harian penjualan terkait aktivitas rutin yang dilakukan. Berkenaan dengan kegiatan uasaha, pencatatan yang dilakukan
Tujuan dari pemasaran adalah untuk meningkatkan volume penjualan usaha, sehingga mendorong pendapatan usaha menjadi meningkat pula. Terkait dengan pemasaran tanaman hias ini, semua pedagang hanya paham bagaimana menjual tanaman hiasnya sehari-hari. Tidak pernah berpikir bagaimana strategi pemasaran yang baik dan lebih efisien serta mampu dilakukan. Semua pedagang tanaman hias lebih banyak menunggu calon pembeli datang ke tempat usahanya, belum ada cara lain yang bisa meningkatkan volume usaha.

Masalah utama yang dialami oleh pedagang tanaman hias yaitu Pemasaran yang sederhana dan belum optimal. Belum menemukan 
pola pemasaran yang efektif yang dapat dikembangkan ke depan. Bukti transaksi yang masih belum memadai. Pengabdian pada masyarakat ini bertujuan memberikan pendampingan dalam Pemasaran dan pencatatan transaksi sederhana pada usaha tanaman hias

\section{METODE PENELITIAN}

Pengabdian kepada masyarakat pada tanaman hias ini menggunakan (field research) yang dilakukan pada pedagang tanaman hias (library research) untuk mendukung informasi yang ada. Dalam pengabdian ini berusaha untuk mendeskripsikan dan membandingkan sistem pencatatan yang ada dengan sistem pencatatan yang seharusnya. lingkungan maupun yang bersifat khusus yang berkaitan dengan proses pencatatan yang saat ini berjalan.

2. Menyusun rencana perbaikan dari hasil survei pendahuluan yang sudah dilakukan dan mengkomunikasikan kepada para pemilik tempat usaha tanaman hias mengenai program yang akan dilaksanakan dan disertai dengan jadwal kegiatan.

3. Pendampingan dalam pemasaran ke konsumen melalui pelatihan pemasaran yang efektif.

4. Pendampingan dalam pencatatan transaksi yang ada di tempat tanaman hias.

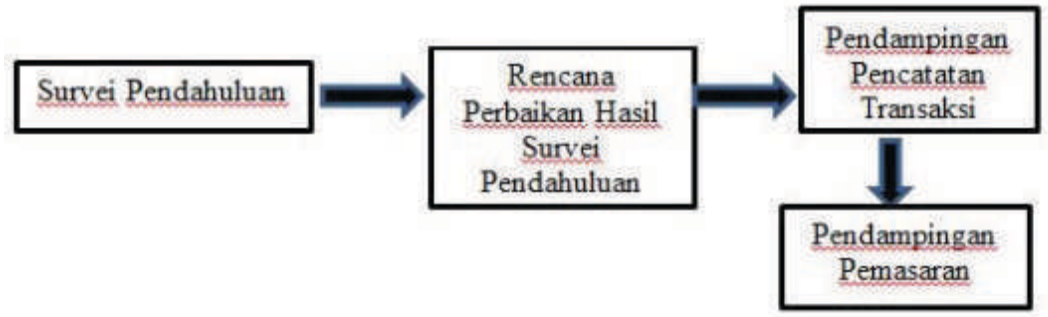

Gambar 2 Metodologi Pelaksanaan Pengabdian

Data utama diperoleh dari para informan yaitu orang-orang yang terlibat dalamkegiatan usahapedagang tanaman hias, sedangkan data pendukung diperoleh dari dokumendokumen berupa catatan, gambar dan bahan-bahan lain yang dapat mendukung dalam pengabdian ini. Pengumpulan data dalam pengabdian ini dilakukan dengan cara:

1. Melakukan survei pendahuluan untuk mengetahui kondisi pedagang tanaman hias secara umum seperti fasilitas dan kondisi

\section{HASIL DAN PEMBAHASAN}

Bulan Desember 2019 sampai Maret 2020 kegiatan pengabdian pada masyarakat yang dilakukan adalah:

\section{Pendampingan Pencatatan Transaksi}

Kegiatan ini dilakukan pada bulan Desember 2019, Januari dan Maret 2020. Pendampingan dilakukan melalui pelatihan dan wawancara kepada seluruh pemilik tempat tanaman hias, karena setiap tempat tanaman hias melakukan pencatatan yang berbeda-beda. Kegiatan ini 
bertujuan untuk :

a. Informasi mengenai bukti transaksi, bukti apa saja yang mereka gunakan dalam kegiatan transaksi sehari-hari baik bukti dokumen yang mereka keluarkan sebagai penjual maupun bukti dokumen yang mereka terima sebagai pembeli tanaman hias.

b. Pencatatan transaksi. Para pemilik tempat tanaman hias yang mengikuti pelatihan terdiri dari kategori usaha mikro. Pencatatan yang dilakukan hanya sebatas Nota/bon penjualan yang tidak selalu dicatat oleh setiap masingmasing pedagang tanaman hias, dan belum mencerminkan pencatatan transaksi penjualan sederhana. Dengan adanya arus masuk dan arus keluar yang harus selalu dicatat di dalam buku kas seperti gambar dibawah ini.

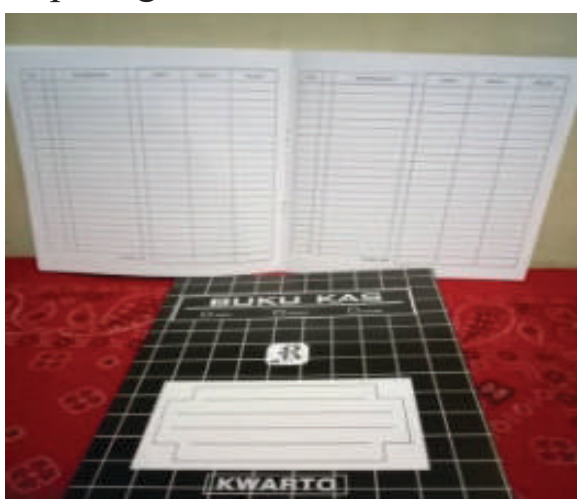

Gambar 3 Buku Kas

\section{Pendampingan Pemasaran kepada Konsumen}

Menurut (Garneti, Anisa Eliana, 2017). Inovasi ini tercipta atas keresahan yang dialami oleh masyarakat Keresahan ini pun dialami oleh para pedagang tanaman hias, antara lain bagaimana menghadapi persaingan perdagangan yang serba online dan bagaimana menembus pasar yang lebih luas. Kondisi ini sudah barang tentu menuntut adanya inovasi dan kreativitas dari para pedagang tanaman hias itu sendiri.

Bandung dengan kota yang sejuk memberikan kemudahan bagi pengusaha tanaman hias. Minat masyarakat terhadap tanaman hias, dikatakan oleh (I.Made Riyan, 2013) khususnya bunga potong, di Kota Bandung dapat dikatakan cukup tinggi tersebar di wilayah Kota Bandung. Hampir setiap hari permintaan akan bunga potong datang dari hotel-hotel, restoran, dan sebagainya.

Langkah selanjutnya yang perlu diperhatikan dalam mengusahakan bisnis ini diantaranya dengan menerapkan (marketing mix) yang terdiri atas produk, harga, tempat, dan promosi, dengan tujuan pedagang tanaman hias nantinya tetap eksis dalam dunia usaha dan mampu memenuhi kebutuhan pasar. (Angipora, 2002).

Guna menjawab tantangan di atas, maka kegiatan pendampingan ini dilaksanakan pada bulan Februari 2020. Pendampingan dilakukan melalui pelatihan kepada seluruh pedagang tanaman hias, khususnya tentang pemasarannya. Pelatihan dilaksanakan sebelum dan sesudah melakukan pendampingan atas pencatatan penjualan sederhana. Kegiatan ini bertujuan untuk :

a. Setelah memahami proses pencatatantransaksibaikpenjualan maupun pembelian tanaman hias, maka pedagang diharapkan mampu memberikan layanan 
terbaik kepada para pelanggannya. Layanan terbaik yang diberikan oleh pedagang tanaman hias akan memberikan dampak positif terhadap peningkatan omzet dan keuntungan. Pada akhirnya, pelayanan yang baik itu akan menjadikan konsumen loyal.

b. Produk-produk tanaman hias yang akan dijual merupakan tanaman yang memiliki kualitas baik. Hal ini dapat dilihat secara fisik, seperti bentuk tanaman, warna daun dan juga akarnya.

c. Sumber daya manusia yang unggul akan memberikan dampak positif dalam pengembangan usaha, baik berbasis teknologi maupun dengan cara memanfaatkan kecangihan teknologi sebagai sarana pemasarannya.

Target dari kegiatan pengabdian pada masyarakat ini bagi mitra adalah:

a. memberikan pendampingan mengenai pemasarann yang optimal.

b. Memberi pendampingan dalam menyiapkan bukti transaksi yang lebih baik serta pengarsipan dokumen transaksi.

c. Memberikan kemudahan dalam melakukan pencatatan keuangan memudahkan pedagang tanaman hias dalampengambilankeputusan yang terkait dengan financial berdasarkan SAK UKM.

Jenis luaran dari pengabdian pada masyarakat ini yang dihasilkan berupa Jasa

a. Pendampingan dalam Pemasaran ke konsumen melalui pelatihan pemasaran yang efektif atau pendampingan selama 1 (satu) bulan.

b. Pendampingan dalam penyiapan bukti transaksi, pendampingan selama 1 (satu) bulan.

c. Pendampingan Pencatatan Penjualan sederhana, pendampingan selama 3 (tiga) bulan.

Produk yang dihasilkan dari penelitian dan pengabdian:

a. Modul berupa manual book mengenai pemasaran yang sederhana dan efektif.

b. Bukti transaksi dengan pengendalian internal yang lebih baik.

c. Modul berupa manual book mengenai pencatatan penjualan.

Dalam kegiatan usaha sudah bisa dipastikan tidak mulus selamanya, pasti ada hambatannya. Hambatan itu selalu ada, baik dilihat sebagai tantangan atau pun sebagai resiko usaha. Hal ini sangat ditentukan dari sudut pandang kita terhadap faktorfaktor tersebut, seperti dalam usaha tanaman hias yang ada di Arcamanik Kota Bandung ini.

Adapun faktor penghambat antara lain :

a. Pemahaman pencatatan penjualan sederhana berbeda-beda sehingga membutuhkan waktu yang cukup serta strategi yang tepat untuk memberikan pemahaman terkait dengan pencatatan penjualan sederhana yang dibutuhkan, sehingga diharapkan semua pedagang tanaman hias mampu mengaplikasikannya dalam 
kegiatan usaha yang mereka lakukan secara berkelanjutan.

b. Waktu yang sangat terbatas untuk melakukan pendampingan melalui pelatihan yang mana para pedagang hanya memiliki sedikit waktu luang untuk mengikuti pelatihan dan pendampingan. Hal ini dikarenakan, aktivitas penjualan tanaman hias yang merekageluti setiap hari. Sehingga untuk melakukan pendampingan melalui pelatihan terkendala. Ada anggapan di para pedagang tanaman hias ini, bahwa kalau jualannya ditinggalkan untuk ikut pelatihan maka usahanya akan rugi.

Adapun faktor pendukung yaitu:

a. Minat dan antusiasme dari para pedagang tanaman hias dalam mengikuti kegiatan pelatihan dan pendampingan sehingga kegiatan dapat terlakasana dengan baik dan lancar dalam suasana yang menyenangkan dan penuh dengan keakraban.

b. Para pedagang tanaman hias tergabung dalam kelompok usaha yang dinamakan "Baraya Kembang", sehingga memudahkan dalam pengkoordinasian pada saat melaksanakan proses pelatihan dan pendampingan.

c. Para pedagang tanaman hias, umumnya sangat terbuka dalam menerima informasi, sehingga memudahkan pada saat penyampaian informasi terkait pentingnya pencatatan penjualan dan pemasaran.

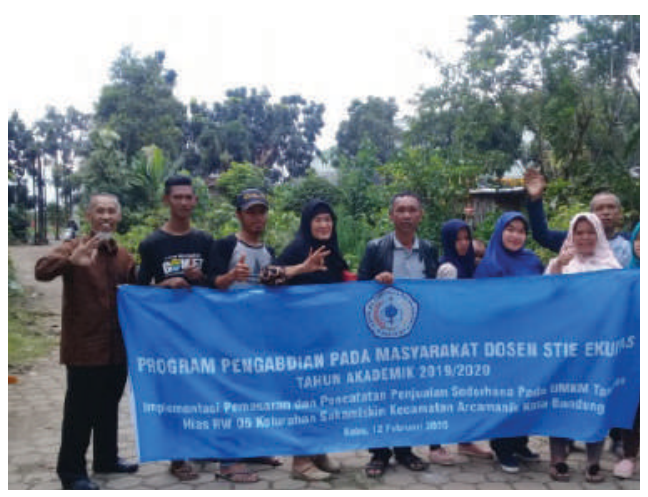

Gambar 4

Pendampingan Pengabdian

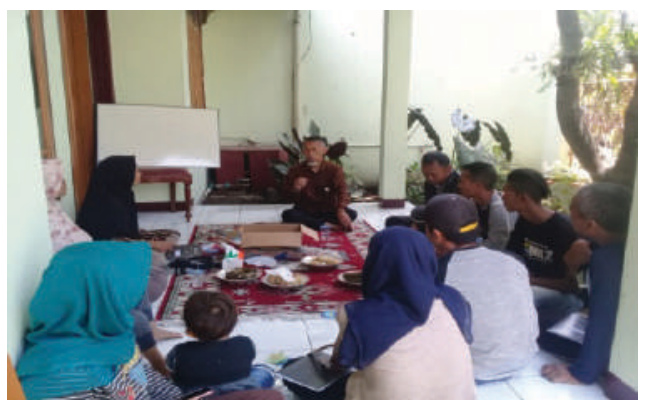

Gambar 5

Pendampingan Pengabdian Kepada Tanaman Hias

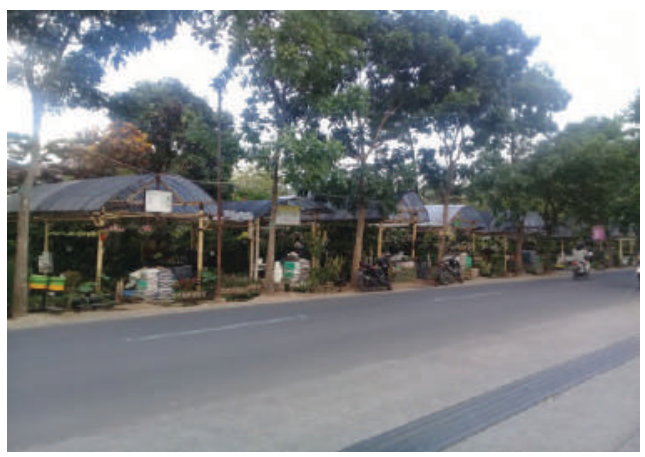

Gambar 6 Lokasi Tanaman Hias 


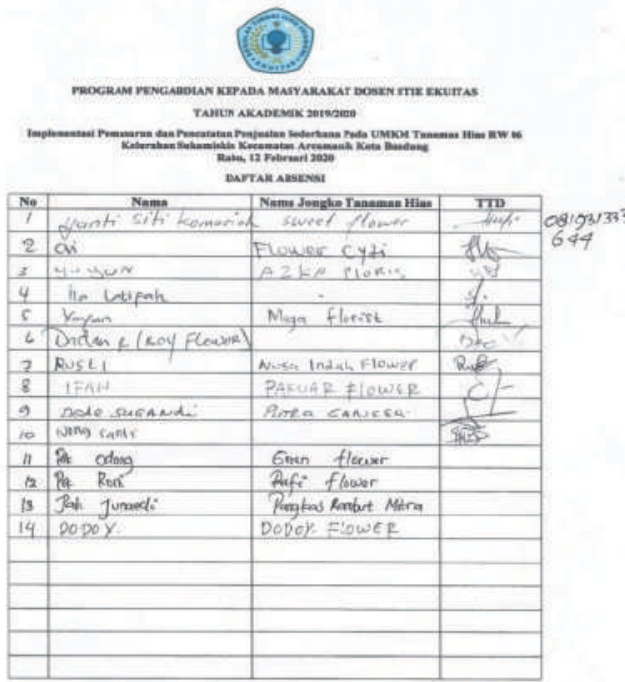

Gambar 7 Daftar Absensi

\section{SIMPULAN}

Berdasarkan hasil penelitian dan pengabdian kepada masyarakat bahwa pedagang tanaman hias menyadari bahwa membuat pencatatan dari transaksi kegiatan penjualan seharihari itu menjadi sebuah keharusan. Pencatatan yang baik harus dilakukan dengan benar. Upaya meningkatkan volume penjualan bagi pedagang tanaman hias yaitu dapat melakukan pemasaran yang optimal dengan menggunakan bauran pemasaran.

\section{DAFTAR PUSTAKA}

Angipora Marius P, (2002). DasarDasar Pemasaran. Jakarta: PT. Raja Grafindo Persada.

Garneti, Anisa Eliana, (2017). Analisis Strategi Pemasaran Dalam Upaya Peningkatan Volume Penjualan Tanaman Hias Boneka Lumut Dengan Media Tanam Kokedama Pada Umkm Planter Craft Bandung. Sarjana thesis, Universitas Brawijaya.

Hall, James, (2016). Sistem Informasi Akuntansi. Edisi Empat. Jakarta: Salemba Empat. Jakarta.
Ikatan Akuntan Indonesia, Standar Akuntansi Keuangan UMKM. Salemba Empat. Jakarta.

I.Made Riyan, (2013). Bauran Pemasaran Bunga Krisan pada Kelompok Usaha Bersama Manik Mekar Nadi di Desa Besakih, Kecamatan Rendang, Kabupaten Karangasem, E-Jurnal Agribisnis dan Agrowisata ISSN: 2301-6523 Vol. 2, No. 1, Januari 2013

Jayanti Mandasari, Dewi et.all, (2019). Strategi Pemasaran Usaha Mikro, Kecil Dan Menengah (Umkm) Batik Magenda Tamanan Kabupaten Bondowoso, Jurnal Pendidikan Ekonomi: Jurnal Ilmiah Ilmu Pendidikan, Ilmu Ekonomi, dan Ilmu Sosial, ISSN 1907-9990 E-ISSN 2548-7175 Volume 13 Nomor 1 2019, DOI: 10.19184/ jpe.v13i1.10432.

Kieso, D. E, Weygandt, J.J, and Warfield, T.D, (2015). Financial Accounting: IFRS Edition. Wiley.

Kotler, Philip and Kevin Lane Keller, (2016). Marketing Management. $15^{\text {th }}$ Edition. New York. Prentice Hall. Pearson International edition.

M. Nurcahyo Rahardi F.; Sri Wahyuni dan E, (1997). Agribisnis Tanaman Hias. Edisi 1, Jakarta: Penebar Swadaya.

Panduan Penelitian dan Pengabdian kepada Masyarakat, Edisi XII, Direktorat Riset dan Pengabdian Masyarakat, Direktorat Jenderal Penguatan Riset dan Pengembangan Kementerian Riset, Teknologi dan Pendidikan Tinggi, 2018. 